\title{
Personality of a Salesman: Evidence From Polish Pharmaceutical Industry
}

\author{
Joanna Żukowska, Mikołaj Pindelski \\ Warsaw School of Economics, Warszawa, Poland
}

\begin{abstract}
The personality as a concept exists for millenniums. Hippocrates divided people according to his approach to personality. Then, Jung, Eysenck, Cattel, even Freud and many other followers presented their own approach to personality as a bunch of features, attitudes, and embedded values. According to their works, it has been presumed that any given individual has own personality that differs her/him from all the others. It also allows use of discrimination analysis in describing groups of people as well as creating personality tests that are widely used in business. On these concepts, however, advisory and other non-scientific literature is blooming. Consultants and consultancy companies propose some other tools as Extended Disc, Hay, and IMMOQEE tools that may mislead managers willing to use one or more of the solution offered. In particular, it is visible that sales departments are facing employees rotation and being helpless in many cases. The paper is to present contemporary approach to personality as a concept used in business. It is also to present approaches to personality testing, and its use and results it may or may not deliver. All is based on the research made in groups of Polish pharmaceutical representatives and their managers. The research sample of sales people has been divided into two groups - top and bottom performers. The personality has been presented in a mode fitted to the sales department requirements. The results are to answer questions: 1. Whether the personality is a useful concept in managing sales people? 2. Do they really differ according to results of their work and personality together? and 3. Is it possible to create the description of a personality that differentiates good and bad sales performers?
\end{abstract}

Keywords: sales, sales management, personality, salesman

\section{Introduction}

Personality, as a term applied in science, seems to enjoy ongoing success. Originally derived from philosophy, through psychology, sociology, psychiatry, and medicine, it has found its place in economics and management sciences. Numerous solutions for the world of business have been prepared in virtue of personality typology offered by more and more authors. Their major target is to facilitate human resources management in organization, particularly the recruitment processes, motivation, supervision, as well as training and general personnel development support. Although the contemporary solutions directed to discover the potential of a manager, but also sales department staff, often try to stay apart from any associations with the original theories of personality, nevertheless, it is difficult to resist the impression that they make the most of them. The more so,

Joanna Żukowska, Ph.D., assistant professor, Institute of International Management and Marketing, Warsaw School of Economics.

Mikołaj Pindelski, Ph.D., assistant professor, Department of Management Theory, Warsaw School of Economics. 
we cannot omit the historical sources in explaining what personality is in general and in definition of its specific type designations.

This is, however, the first step of these studies. The second step is to define the set of most desired characteristics of a sales representative - in this case study - the characteristics of a pharmaceutical sales representative. The characteristics have been distinguished upon comparison of the bottom performers to the top performers within the period analyzed, i.e., 3-6 months. On such foundation, the characteristics that most often occur as differences between the group of top performing sales representatives and the bottom performers have been selected out of the original list of characteristics distinguishing them.

The third step of the study comprised distinguishing of the characteristics capable of building the "personality" of a sales representative. It was also connected with a test of the hypothesis whether personality existed in the researched sample. In effect, this is translated into the potential usability of the methods and tools utilizing personality typologies for supporting the management processes at the sales department and the possibility to settle personnel development directions on their foundation.

\section{Personality}

The term "personality" is relatively controversial, not as much in terms of its designations, but rather in terms of the consequential typologies and specific "labeling" of people basing on a predetermined type of personality. Determination of any rigid boundaries between the personalities of individual people may, thus, become a serious abuse, all the more that the very definition of personality is not clear, so the assumptions made in its definition can easily be falsified.

Hall, Lindzey, and Campbell (1997) fully described personality from the historic aspect. They mentioned a number of theories of personality, such as psychodynamic (Sigmund Freud), in which childhood experiences, relationships with the guardians, and biological instincts decide on its form. The new psychoanalytic theory adds social relationships thereto (Carl Jung and Karen Horney). Field theories (Kurt Goldstein) approach a human being holistically and give special importance to self-realization. According to factor theories (Hans Eysenck), personality is a set of characteristics, responses, and behavior characteristics for a person. The situational dynamic theories related to the possibility of forming personality through education refer to the circumstances in which personality occurs, and (Iwan Pawłow) factors enhancing some stimuli from the environment and forming new behaviors, thus also influencing personality. The expansion of the theory is the formation of attitudes and behaviors within so-called key behaviors (Alfred Bandura) and those conditioned by the impact of the community an individual lives in. The humanist theories (Abraham Maslow) include external and internal stimuli, however, mainly within a specific person and his/her motives for action. System theories (Virginia Satir) place a human being and his/her personality as an element of a complex system, interrelating with all the external elements and his/her sets. This takes place to such an extent that it is difficult to establish personality in separation from the environment it occurs in.

As a result of the analysis of the entire set of the theories quoted, somewhat generalizing them, three basic groups of personality definitions can be enumerated. The first one is a set of internal standards, values, predispositions, and experiences expressed in thoughts, feelings, behaviors, and characteristics, we are often unaware of, from the point of view of people, relatively permanent in time and space. The set is complicated and unique and the discriminative analyses of its types may take place with the assumption of significant simplifications and inaccuracies. The second one refers mainly to the characteristics the origin whereof is 
conditioned by factors in so much complex and unknown that their analysis does not make much sense. They originate both from physicality, anthropology, and external conditions. The fairly permanent characteristics, disregarding the way they have been formed, form the key object of interest here. The third one is focused on the behaviors that may result from characteristics, but also situations and time. These are relatively durable methods of response and human activity is the basic designation.

Thus, the approaches to personality and its notional designations are so numerous that its explicit definition becomes impossible. Some researchers apply an evasion here, selecting or formulating a definition adequate to the research purposes they carry out and the scientific tendency they prefer. So, Livesley (2003), for example, referred to personality in a way characteristic for medical sciences. This is most of all the sense of identity. Homogeneous, related to the attitudes, behaviors, and characters in general, is the reference point in search for deviations from the standard set in this way. And this happens when the behaviors and attitudes of a person, under certain conditions, deviate from his/her most frequent behaviors and attitudes.

Combining the approaches and theories presented above, for the purposes of further considerations, we may assume that personality is a set of psycho-physical characteristics, both permanent and variable, related to their behaviors and responses to external stimuli.

\section{Typologies of Personality}

Based on personality analysis, numerous typologies thereof have been developed. The presentation in this point of several leading examples or perhaps ones most frequently encountered in literature is reasonable, as this was shown as early as in the 1930's by Allport and Odbert (1936), the descriptive characteristics in virtue whereof one type of personality may be distinguished from another amount to almost 18,000 , more accurately to 17,953 . On Page 178 of their paper, they specified them all in detail, bringing about a substantial chaos in thinking of personality typologies. Nevertheless, the particular division into types appears fairly frequently and is based on various factors.

The original division into types was simple and intuitive. It helped understand the complex human nature and was often based on heuristics, which is noticeable in the division suggested by Hippocrates (460-370 BC). He made the now debunked assumption that a human being as a physical entity is composed of four humors-blood, phlegm, yellow bile, and black bile. Basing thereon, he deduced that the person in whom a specific humor prevails or simply occurs in larger volume than the others, dominates the specific type of personality attributed to such humor. Thus, where blood dominates, a sanguine is produced $^{1}$, phlegm-a phlegmatic, black bile - a melancholic, and yellow bile - a choleric. Also at present, references can be found to this slightly archaic typology, with wide expansions thereof, descriptions of characteristics, and even projection of professions and activities persons of specific personality should or may perform (see Table 1).

As presented in Table 1, even basing on types of personality so archaic as those suggested by Hippocrates and based on assumptions falsified a long time ago, an immense superstructure has been created contemporarily to indicate the strong and weak points of people with particular personality types, their behaviors, stimuli, and conditions searched for and even the indications for the professions and activities they should perform.

\footnotetext{
${ }^{1}$ Sanguine (pleasure-seeking and sociable), choleric (ambitious and leader like), melancholic (analytical and thoughtful), and phlegmatic (relaxed and quiet).
} 
On the one hand, this would indicate that such approach and its substantial usefulness are deeply rooted in the social and research consciousness. On the other hand, however, the conclusions so wide, making an impression of highly practical potential application, drawn based on false assumptions may discredit the reasonability of defining and distinguishing personalities in general.

Table 1

Personality Characteristics Based on Hippocrates Typology

\begin{tabular}{|c|c|c|c|c|}
\hline & Sanguine & Melancholic & Choleric & Phlegmatic \\
\hline \begin{tabular}{|l|}
$\begin{array}{l}\text { Dominating } \\
\text { characteristic }\end{array}$ \\
\end{tabular} & $\begin{array}{l}\text { Sociable, getting into } \\
\text { social relationships }\end{array}$ & $\begin{array}{l}\text { Perfectionist, searching } \\
\text { for perfection }\end{array}$ & $\begin{array}{l}\text { Imperiousness, fighting } \\
\text { for domination }\end{array}$ & $\begin{array}{l}\text { Peacefulness, avoiding } \\
\text { any turbulences }\end{array}$ \\
\hline Strong points & $\begin{array}{l}\text { Sense of humor, } \\
\text { optimism, making contact } \\
\text { easily, and freedom of } \\
\text { speech }\end{array}$ & $\begin{array}{l}\text { Organized, orderly, } \\
\text { accurate, systematic, just, } \\
\text { empathic, individual } \\
\text { approach to life, } \\
\text { analyzing environment }\end{array}$ & $\begin{array}{l}\text { Activity and ability to } \\
\text { make fast decisions, } \\
\text { particularly in difficult } \\
\text { situations, decisiveness, } \\
\text { need to lead and } \\
\text { dominate, } \\
\text { self-confidence, and likes } \\
\text { challenges }\end{array}$ & $\begin{array}{l}\text { Quiet and silent, enjoying } \\
\text { popularity of the } \\
\text { neighborhood, } \\
\text { non-conflicting, good } \\
\text { listener, intermediate, } \\
\text { negotiator, } \\
\text { self-controlled, modest, } \\
\text { reliable, polite, but also } \\
\text { conscientious } \\
\end{array}$ \\
\hline Weaknesses & $\begin{array}{l}\text { Low level of } \\
\text { assertiveness, overloaded } \\
\text { with their role and } \\
\text { consequential delays, } \\
\text { forgetting, chaos in the } \\
\text { tasks }\end{array}$ & $\begin{array}{l}\text { Lack of spontaneity, } \\
\text { varying moods, } \\
\text { depressiveness, slow } \\
\text { decision-making or } \\
\text { avoiding decisions, and } \\
\text { time-consuming search } \\
\text { for perfection }\end{array}$ & $\begin{array}{l}\text { Arrogance, inability to } \\
\text { lose and admit to have } \\
\text { made mistakes, } \\
\text { nervousness, excessive } \\
\text { self-confidence, blunt } \\
\text { stubbornness, difficulties } \\
\text { at making and } \\
\text { maintaining social links, } \\
\text { searching for domination, } \\
\text { manipulator } \\
\end{array}$ & $\begin{array}{l}\text { Introvert, stubborn, } \\
\text { hesitant, difficulties at } \\
\text { committing into actions, } \\
\text { and procrastination }\end{array}$ \\
\hline $\begin{array}{l}\text { Distinctive } \\
\text { characteristics }\end{array}$ & $\begin{array}{l}\text { Struggles for } \\
\text { acknowledgement, } \\
\text { creative mess in } \\
\text { workplace, and } \\
\text { sometimes extravagance }\end{array}$ & $\begin{array}{l}\text { Simple form, care about } \\
\text { details combines with } \\
\text { high quality, } \\
\text { conservatism, and } \\
\text { elegance }\end{array}$ & $\begin{array}{l}\text { Task maturity and target } \\
\text { orientation, } \\
\text { hard-working, need for } \\
\text { respect and recognition, } \\
\text { workplace is orderly, } \\
\text { although maintained in } \\
\text { high simplicity }\end{array}$ & $\begin{array}{l}\text { Searches for } \\
\text { acknowledgement and } \\
\text { respect, strong sense of } \\
\text { their own value, } \\
\text { individualist, appreciates } \\
\text { functionality and comfort } \\
\text { at work, also searches for } \\
\text { comfort in life }\end{array}$ \\
\hline $\begin{array}{l}\text { Expressions } \\
\text { searched for in } \\
\text { business } \\
\text { relationships } \\
\end{array}$ & $\begin{array}{l}\text { Free, funny, and giving } \\
\text { joy }\end{array}$ & $\begin{array}{l}\text { Detailed, practical, and } \\
\text { sensitive }\end{array}$ & Practical and courageous & $\begin{array}{l}\text { Easy to use, relaxing, } \\
\text { requiring no commitment } \\
\text { and studying }\end{array}$ \\
\hline $\begin{array}{l}\text { Selected } \\
\text { professions/positions }\end{array}$ & $\begin{array}{l}\text { Advertising specialist, } \\
\text { sales representative, } \\
\text { instructor, tour guide, } \\
\text { stewardess, and stage } \\
\text { performer }\end{array}$ & $\begin{array}{l}\text { Pharmacist, scientist, } \\
\text { accountant, engineer, } \\
\text { economist, notary, } \\
\text { conservator of historical } \\
\text { monuments, librarian, } \\
\text { archeologist, and weather } \\
\text { forecaster }\end{array}$ & $\begin{array}{l}\text { Manager, businessman, } \\
\text { engineer, foreman in } \\
\text { industry and construction, } \\
\text { tradesman, lawyer, } \\
\text { journalist, film director, } \\
\text { and policeman }\end{array}$ & $\begin{array}{l}\text { Physician, teacher, clerk, } \\
\text { sociologist, psychologist, } \\
\text { scientist, artist, librarian, } \\
\text { and literature critic }\end{array}$ \\
\hline $\begin{array}{l}\text { Selected professions } \\
\text { divergent to the type } \\
\text { of personality }\end{array}$ & $\begin{array}{l}\text { Accountant, economist, } \\
\text { laboratory assistant, } \\
\text { manager, and lawyer }\end{array}$ & $\begin{array}{l}\text { Actor, sales person, } \\
\text { manager, sales } \\
\text { representative, lawyer, } \\
\text { stockbroker, and assistant }\end{array}$ & $\begin{array}{l}\text { Accountant, office } \\
\text { worker, and pharmacist }\end{array}$ & $\begin{array}{l}\text { Sales representative, } \\
\text { manager, tour guide, } \\
\text { policeman, and controller }\end{array}$ \\
\hline
\end{tabular}

Note. Source: The author's own study (http://archive.endemic.org/nmm/nrlosobow.html).

Jung (1990) presented a slightly different approach to personality. He defined the scale described on one extreme as introversion, while the one on the other as extraversion and assumed that the space between them is 
a continuum and the specific types of personality may be defined within its framework. Introversion is focused on its own internal world, while extraversion is oriented on the stimuli from the environment and the basis of the typology called with some exaggeration, classification has been formed by such dimensions as: thinking, feelings, impressions, and intuition. Thinking defines the way of perceiving oneself and the surrounding reality. Feelings enable definition of a system of values and emotions subjectively perceived, such as pain, joy, fear, and pleasure. Impressions consolidate events and their situational perception. Intuition goes beyond all the stereotypes, enabling to create the perception of the environment and assessment of events in an extrasensory way. Based on this, he specified 16 types of personality and suggested a test enabling the settling and measurement of them. For example, the Extended Disc, officially renouncing it, but also the Myers-Briggs Type Indicator (MBTI) index suggested by Myers and Briggs based on the pairs extraversion-introversion, intuition-impressions, thinking-feelings, and evaluation-observing. The conclusions became so convincing that in the 1980's, a personality MBTI-based test was carried out on a research sample of 1.5 million (Greenberg \& Baron, 1993).

The extent the search for personality types can meander is presented, for example, by Sheldon (1942), who assumed that physical features are closely correlated with the features of character of the specific persons. He specified three types of personality correlated with description of physical attributes. The physiognomy resulting from characteristics and describing personality becomes a certain abuse, although there are numerous continuators of this kind of considerations. In extreme cases, they tend towards dangerous and by nature untrue approaches, such as eugenics evoking racism and discrimination.

Basing on the approaches presented herein, for example, we may draw a conclusion that producing sets of activities and professions predestinated to be performed by the specific types of personality described by the set of characteristics. So, it is reasonable to make a hypothesis on the existence of personality related to the work of a sales representative, including a pharmaceutical sales representative. If the hypothesis appears to be true, an attempt to describe this type of personality will be made, called for the purposes of this paper, the sales person's personality.

\section{Personality of a Salesman}

Paul T. Costa Jr. stated that personality of an individual is largely durable and permanent (Goleman, 1987). He also offered a 5-factor personality model (Costa \& McRae, 1988) based on dimensions of Neuroticism, Extraversion, Openness, Agreeableness, and Conscientiousness. The author is not the only one defining personality in this way. The dimensions have been noticed by Tupes and Christal (1961), Lanning (1994), Saucier (1997), and others. So, their evidence in literature is significant and this is where we should search for personality of a salesman, if any. The psychological tests, such as Minnesota Multiphasic Personality Inventory (MMPI), Enneagram, or Oldham and Morris test, also refer to such dimensions in a sense. Basing on this kind of instruments, the diagnostic apparatus have been developed, related to the specific professions, including a sales representative (including a pharmaceutical sales representative), and tasks performed in organizations, such as carrying out changes (Dubinsky, Yammarino, \& Jolson, 1995).

Numerous references to the personality of a salesman may be found in literature, particularly manuals where a combination of behaviors, characteristics, attitudes, and skills forms a set of a few to a few dozen of, so-called, salesman's attitudes (Martin, 2011; Khanna, 2011; James, 2012; Young Entreprenur Council (YEC), 2013). They are also present in scientific literature (Vinchur, Shippmann, Switzer, \& Roth, 1998; Crant, 1995). 
Vinchur et al. (1998) summarized the existing considerations on the set of features and indirectly, the personality of sales people. They described them by means of five features: (a) extraversion; (b) orientation on targets and tasks - conscientiousness; (c) teamwork ability—affiliation; (d) potential of development and achieving better than standard performance - potency; and (e) reliability and trustworthiness - dependancy. They found the strongest correlations between the sales performance and intensity of a feature between extraversion and conscientiousness. As a result, they suggested that the two variables can be considered in the possible description of a salesman's features.

Empathy and the features and attitudes related thereto, such as friendliness, orientation on cooperation, helpfulness, etc., as not correlated with the sales performance, are presented by Mount and Barrick (1995). This is also pointed out by Warr, Bartram, and Martin (2005), who wrote that in addition to empathy, or even more than that, aggression, related to soliciting clients, besieging them and creating their needs are necessary, at least situationally (Warr et al., 2005).

Basing on the indications of the said authors describing the types of personality predisposed to the role of a sales representative, the selection of characteristics most frequently indicated as describing a good salesman has been analyzed. They included ones occurring particularly frequently, such as:

1. Ability to empathize with the client's needs (James, 2012), ability to listen and respond to the clients' demands (Mayer \& Greenberg, 1964), discovering their present and future needs (Anselmi \& Zemanek, 1997), respect to the clients (Mount \& Barrick, 1995, pp. 161-165), and using good manners (Khanna, 2011) which was included in the term "empathy";

2. Self-confidence (Mayer \& Greenberg, 1964), aiming at the target (Churchill, Ford, \& Walker, 1997; Futrell, 1994), orientation on closing sales, courage, and taking up initiative (Khanna, 2011), called "aggression" here;

3. Willingness to earn or tendency to improve one's own financial status (Dweck, 2007) called "money focus" here;

4. Target maturity (Khanna, 2011), willingness to perform interesting targets, ambition, aiming at interesting targets (Comer \& Dubinsky, 1985) called "task focus";

5. Planning, fulfilling plans (Pindelski, 2011), setting targets for oneself, called "planning" here;

6. Ability for quick decision-making, decisiveness (Mount \& Barrick, 1995, pp. 161-165; Mount, Barrick, \& Stewart, 1998), ability to cope with difficult situations (Khanna, 2011), called "fast decision-making" here.

This is of course a set of characteristics largely not exhausting the description of a salesman's personality, particularly in relation to the numerous group of approaches and authors representing them. However, as the said characteristics most frequently occurred in the literature references analyzed, it seems reasonable to carry out a test whether the characteristics really distinguish the personality of a salesman from that of a non-salesman. Therefore, it was assumed that in this project, the list would be closed in this was and assumed as such would represent input materials for further research.

\section{Main Assumptions of the Study}

The purpose of the study was to define and describe the personality of a sales representative and, in the case study analyzed, the personality of a pharmaceutical sales representative. For this purpose, the division was made into the representatives with the best results or, in the managers' opinion, offering the best projections for 
the nearest future or ones whose dynamics of result growth has been significant and durable for the last six months. Similar method has been used in the research conducted by Warr et al. (2005). On such foundation, a reference group of the best sales people (top performers) has been distinguished. On the other extreme of the scale, if we talk about a scale here, those with the lowest sales performance for the last few months were placed. The difficulty in this point appeared in distinguishing those who had low performance (bottom performers) for the last six months, as such employees were dismissed from their jobs within such a long time. Therefore, in the case of determining the employees with bottom sales performance, a period of three months preceding the test was applied.

The research hypothesis, however, was the finding that there is a personality of a sales person. It must have been different enough from the personality of a non-sales representative, in order to distinguish unique psycho-physical features, behaviors, etc., according to the personality definition assumed.

Two Polish divisions of overseas pharmaceutical corporations and one large Polish pharmaceutical company participated in the study. They did not give permission, however, to publish their names. Finally, 220 pharmaceutical representatives were accepted to the research sample and were divided into two groups - the top performers $(N=130)$ and the bottom performers $(N=90)$. The study was carried out in the years 2010-2012.

Like in the method suggested by Jung (1990) and the continuators of his ideas, the study was made in virtue of putting sets of characteristics and behaviors into pairs, sometimes grouped and on such foundation the subsets in the major set of the subjects, the occurrence of a given characteristic and behavior were settled on such foundation. The following pairs of characteristic sets have been settled:

(a) Aggression vs. empathy;

(b) Money focus $v s$. task focus;

(c) Planning vs. quick decision-making.

Each characteristic was assessed according to a 10-grade scale. The scale of 1 whereof meant the bottom intensity of a characteristic, and 10 the top one. The final assessment was made by the researcher who issued it basing on the findings of an employee, assessment made by his boss and own observation made by the researchers.

Certainly, the pairs of such attitudes or behaviors do not exhaust their entire list describing personality, which is indicated by the conclusions quoted by Allport and Odbert, for example. However, the purpose was to test if it is possible to indicate whether the top performers differ from the bottom ones, within the characteristics, attributes, behaviors, and attitudes most often used in the personality description in any way connected with the sales representative. In the case of a positive verification, the determination of a sales representative personality only can be started.

Although basing on the subjects' declarations only and drawing conclusions thereon was originally tempting, it would lead to use mainly tests and possibly open questions. As the authors approached the present solutions and the general idea of determining the types of personality with reserve, the test was replaced with interviews with the employees $(N=220)$, their bosses, and own observations of all the subjects for at least half of the working day of each of the subjects.

\section{Test Results}

As a result of the tests carried out, based on semi-structured interviews with the subjects and their 
supervisors as well as on the working day observations, the issues related to the settled three pairs of attitudes connected to the sales people activity have been raised. The specific diagrams present the assessment marks within the characteristic pairs of the "top performers" group representatives and those of the "bottom performers". The preliminary statistical analysis confirmed that the results are normal distribution and may be subjected to statistical analysis.

For the pair of characteristics "empathy $v s$. aggression" (see Figure 1), the test results indicate that in the top performers group, the results for the variable "aggression" were generally close to those for the bottom performers. The analysis of the averages and median indicates that the difference in results applies to empathy (see Table 2). In the top performers group, the dispersion of the layout is larger, while the correlation of the two variables is lower. This would mean that in the case of the bottom performers group, both variables occur on an approximate level much more frequently. At any rate, there is a certain co-occurrence of the variables of empathy and aggression. In the top performers group, the variables do not necessarily co-occur, while their dispersion impedes the determination that these are characteristics explicitly discriminating the two sets. For the bottom performers group, the distribution of the results for empathy indicates its left-side skewness, while in the top performers group, this is right-side skewness.

In the analysis of the pair of characteristics "money focus vs. task focus" (see Table 3), most of all indicates a negative correlation between the result for the bottom performers group characteristics results. This has been illustrated in Figure 2 in the form of the negative function course. In as much the specific results indicate a certain difference in the scope of task focus, where the top performers group presented higher results, in so far basic is the negative dependency between the characteristics values in the bottom performers group and positive in the top performers group. In the top performers group, like for the previous pair of characteristics, the distribution dispersion was higher. In the bottom group, for the characteristic the task focus layout is strongly left-side skewness, which would indicate more frequent occurrence of results below the median in this group for this characteristic.

Like for the previous pair, in the case of "planning vs. quick decision-making" characteristics (see Figure 3 ), in the bottom performers group, the correlation and course of the curve are negative. The distributions in this group are left-side skewness. The averages for both groups are approximate, while the medians are the same. Therefore, this is not the characteristic value that could represent a difference between the two groups, but co-occurrence of the variables (see Table 4).

As shown in Table 5, the correlation of the specific variables in the research sample more often shows negative values in the bottom performers group than in the top performers group. At the same time, the correlation coefficients in the bottom performers group are generally lower, which would indicate no co-occurrence of variables analyzed in this sample. This may also mean that the selected characteristics rather apply to the group predestinated to the salesman profession, while they do not correspond with the description of other groups. This would be in a sense the confirmation of existence of a salesman's personality. However, this cannot be said explicitly, as the correlations in the top group are not too high. This might as well mean that the variables do not match the description of a sales person's personality at all and we must search for other or no salesman's personality occurs in the group tested. 

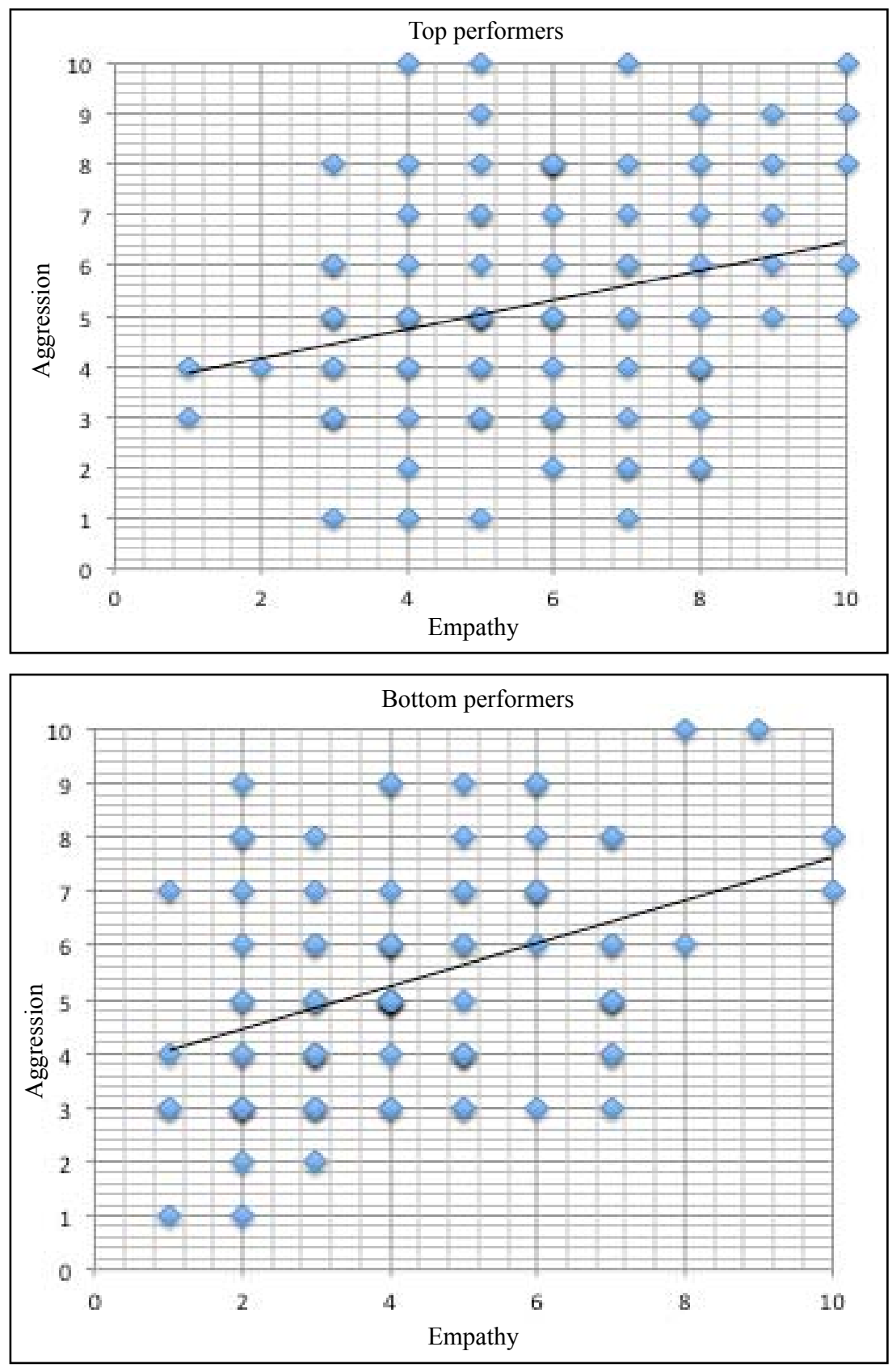

Table 2

Figure 1. "Aggression vs. empathy" test results (Source: The author's own study).

Basic Statistics for the Pair of Characteristics “Empathy vs. Aggression”

\begin{tabular}{llllll}
\hline & \multicolumn{2}{c}{ Top } & & Bottom \\
\cline { 2 - 3 } & Empathy & Aggression & & Empathy & Aggression \\
\hline Average & 5.76 & 5.27 & 4.30 & 5.37 \\
Mean & 6.00 & 5.00 & 4.00 & 5.00 \\
$S D$ & 2.15 & 2.27 & 2.07 & 2.06 \\
Correlation & 0.28 & & 0.40 & \\
Bias & 0.12 & 0.23 & 0.56 & 0.26 \\
\hline
\end{tabular}

Note. Source: The author's own study. 

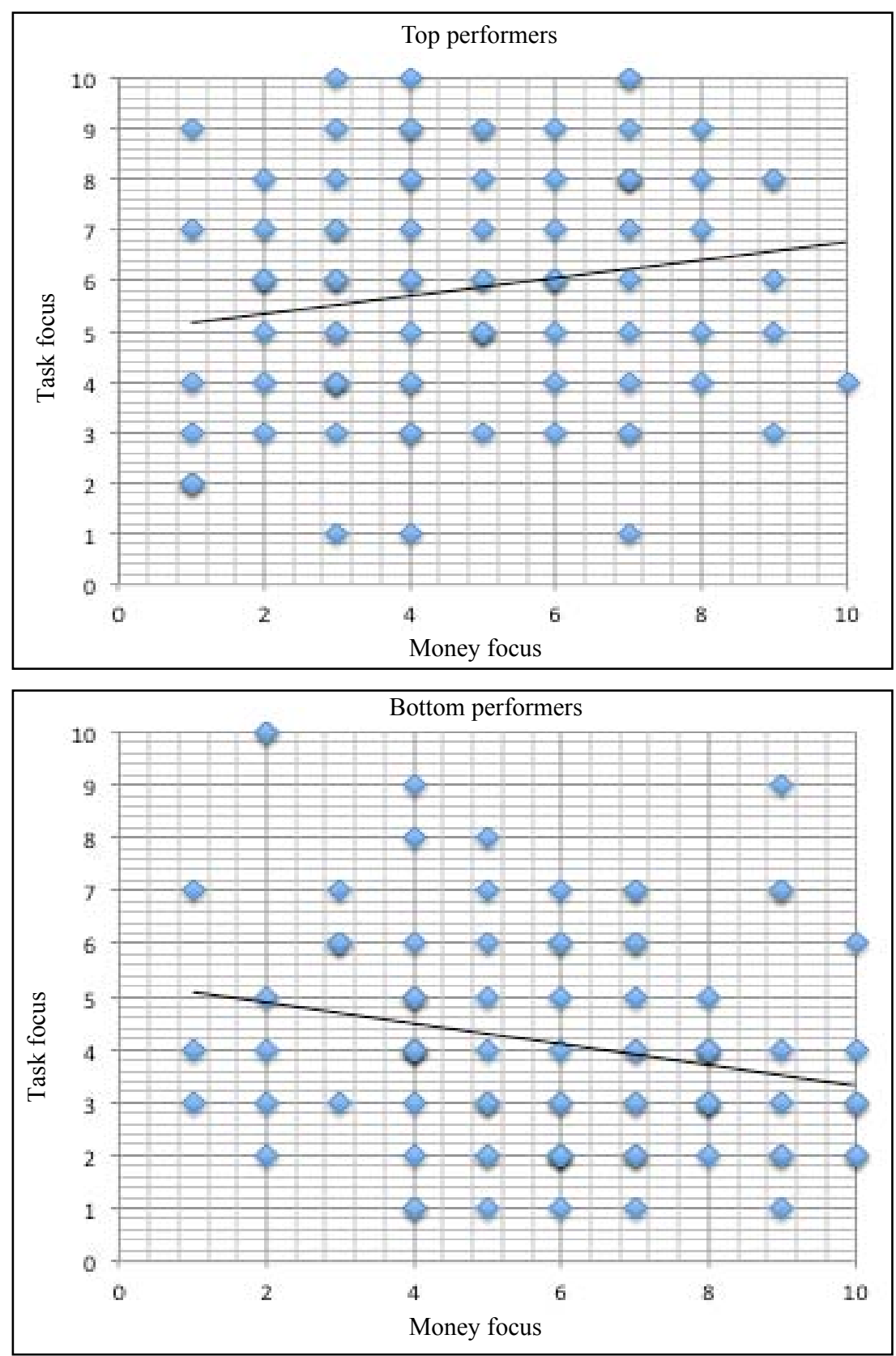

Figure 2. "Money focus vs. task focus" test results (Source: the author's own study).

Table 3

Basic Statistics for the Pair of Characteristics: Money Focus vs. Task Focus

\begin{tabular}{llccc}
\hline & \multicolumn{2}{c}{ Top } & & \multicolumn{2}{c}{ Bottom } \\
\cline { 2 - 3 } \cline { 5 - 5 } & Money focus & Task focus & Money focus & Task focus \\
\hline Average & 5.01 & 5.66 & 5.84 & 4.13 \\
Mean & 5.00 & 6.00 & 6.00 & 4.00 \\
$S D$ & 2.25 & 2.26 & 2.37 & 2.14 \\
Correlation & 0.17 & & -0.22 & 0.73 \\
Bias & 0.16 & -0.17 & -0.08 & 0.08 \\
\hline
\end{tabular}

Note. Source: The author's own study. 

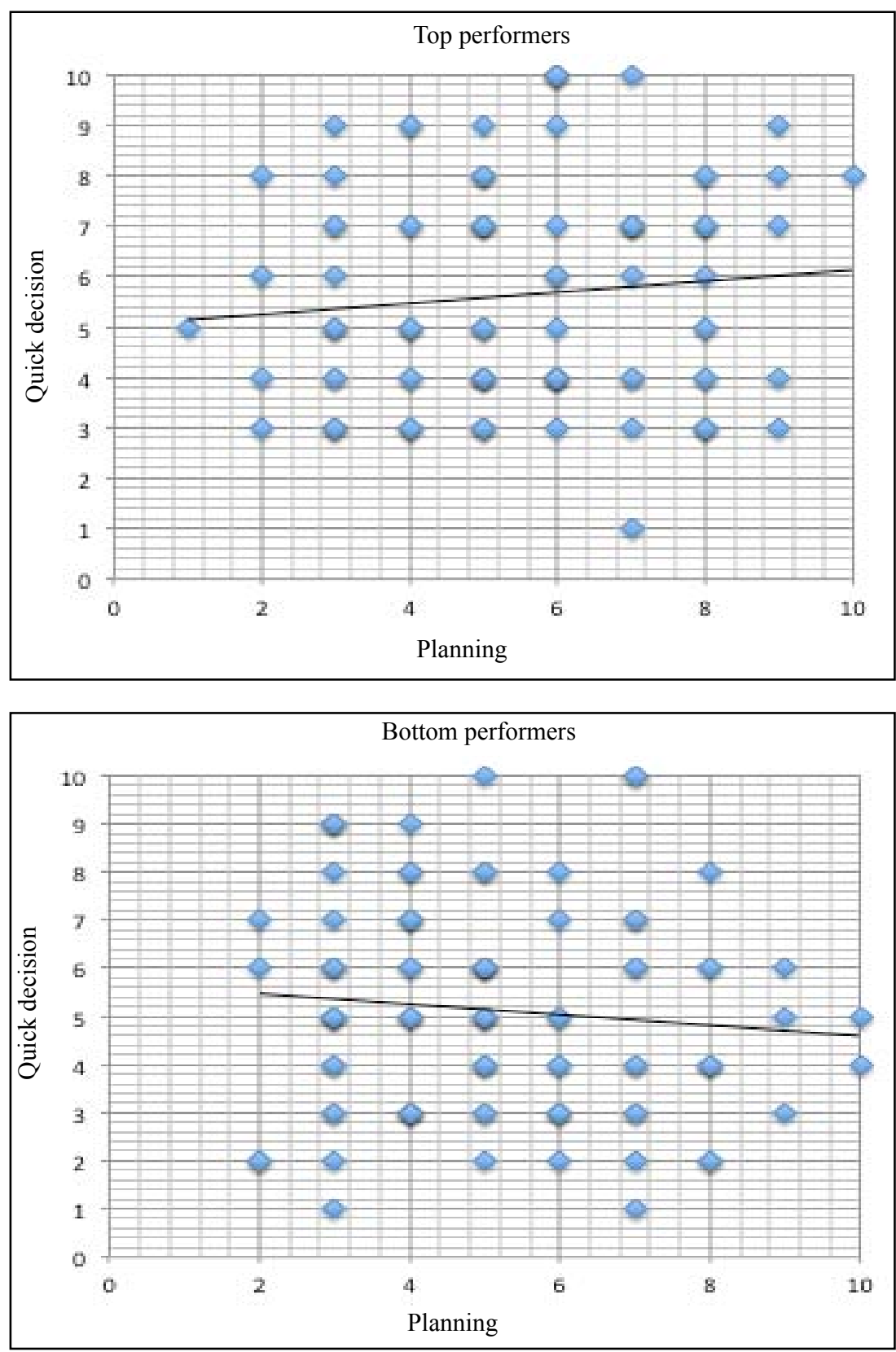

Figure 3. "Planning vs. quick decision-making" test results (Source: the author's own study).

Table 4

Basic Statistics for the Pair of Characteristics "Planning vs. Quick Decision"

\begin{tabular}{|c|c|c|c|c|}
\hline & \multicolumn{2}{|c|}{ Top } & \multicolumn{2}{|c|}{ Bottom } \\
\hline & Planning & Quick decision & Planning & Quick decision \\
\hline Average & 5.48 & 5.63 & 5.19 & 5.12 \\
\hline Mean & 5.00 & 5.00 & 5.00 & 5.00 \\
\hline$S D$ & 2.03 & 2.14 & 1.97 & 2.16 \\
\hline Correlation & 0.10 & & -0.10 & \\
\hline Bias & 0.08 & 0.29 & 0.45 & 0.31 \\
\hline
\end{tabular}

Note. Source: The author's own study. 
Table 5

Correlation Matrix

\begin{tabular}{|c|c|c|c|c|c|c|c|}
\hline & Empathy & Aggression & Money focus & Task focus & Planning & Quick decision & \\
\hline Empathy & $x$ & 0.40 & 0.01 & 0.17 & -0.01 & -0.18 & \multirow{7}{*}{ 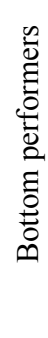 } \\
\hline Aggression & 0.28 & $x$ & -0.07 & 0.11 & -0.09 & -0.06 & \\
\hline Money focus & 0.24 & 0.06 & $x$ & -0.22 & 0.04 & -0.06 & \\
\hline Task focus & 0.17 & 0.16 & 0.17 & $x$ & 0.07 & -0.05 & \\
\hline Planning & 0.04 & -0.03 & 0.00 & -0.08 & $x$ & -0.10 & \\
\hline \multirow[t]{2}{*}{ Quick decision } & 0.02 & 0.11 & 0.07 & -0.15 & 0.10 & $x$ & \\
\hline & \multicolumn{6}{|c|}{ Top performers } & \\
\hline
\end{tabular}

Note. Source: The authors' own study.

\section{Conclusion}

Although there are differences between the sets of bottom performers and top performers, however, they do not seem to indicate explicitly any significant differences in the characteristic values. It concerns more the course of the function determined by the pairs of variables, i.e., the principles they co-occur under. In this scope, however, the results are in as much explicit and the sample numerous that they can indicate the set of characteristics distinguishing the two groups. Based on this test, however, we may set a hypothesis that the top performers group is mother empathic and task focused than the bottom performers group. Moreover, in the top performers group within the suggested pairs of characteristics, the results indicate their positive correlations and such course of the functions determined by them. This already could be a certain guideline for the practical application of results to sales department management.

However, based on the results obtained, any significant differences between the group of pharmaceutical representatives groups could not be explicitly defined. Although they occurred, nevertheless, they were explicit and distinct enough to confirm the existence of a salesman's personality with high amount of certainty. The use of tools supporting management and based on theories and typologies of personality, in virtue of the test result could be defined as rather useless as long as they are only based on the statistical analysis of values of any characteristic intensity, whatever way it was evaluated. However, a dynamic analysis could provide good results, one assuming the co-occurrence and perhaps even correlations between numerous characteristics co-occurring at the same time. Therefore, some multi-dimensional tools should be used, utilizing the analysis of dependencies between numerous variables. A simple specification of characteristics results based on the statistical analysis of questionnaires may not represent a sufficient aid in management and lead to a wrong interpretation of a certain set thereof as the salesman's personality.

\section{References}

Allport, G. W., \& Odbert, H. S. (1936). Trait-names: A psycho-lexical study. Psychological Monographs, 47(211), 1-178.

Anselmi, K., \& Zemanek, J. E. Jr. (1997). Relationship selling: How personal characteristics of salespeople affect buyer satisfaction. Journal of Social Behavior and Personality, 12(2), 539-550.

Bandura, A. (1975). Social learning \& personality development. New York, N.Y.: Holt, Rinehart \& Winston.

Churchill, G. A. Jr., Ford, N. M., \& Walker, O. E. Jr. (1997). Sales force management. Chicago, I.L.: Irwin.

Comer, J., \& Dubinsky, A. J. (1985). Managing the successful sales force. Lexington, M.A.: D. C. Heath.

Costa, P. T. Jr., \& McRae, R. R. (1988). From catalog to classification: Murray's needs and the five-factor model. Journal of Personality and Social Psychology, 55, 258-265. 
Crant, J. M. (1995). The proactive personality scale and objective job performance among real estate agents. Journal of Applied Psychology, 80, 532-537.

Doob, L. W. (1983). Personality, power, and authority: A view from the behavioral sciences (Series: International Contributions in Psychology, Book 1). Westport, C.T.: Greenwood Press.

Dubinsky, A. J., Yammarino, F. J., \& Jolson, M. A. (1995). An examination of linkages between personal characteristics and dimensions of transformational leadership. Journal of Business and Psychology, 9(3), 315-335.

Dweck, C. (2007). Mindset: The new psychology of success. New York, N.Y.: Ballantine Books.

Futrell, C. (1994). Sales management. Fort Worth, T.X.: Dryden Press.

Goleman, D. (1987, June 9). Personality: Major traits found stable through life. New York Times.

Greenberg, J., \& Baron, R. A. (1993). Behavior in organizations: Understanding and managing the human side of work (4th ed.). Needham Heights, M.A.: Allyn and Bacon.

Hall, C. S., Lindzey, G., \& Campbell, J. B. (1997). Theories of personality (4th ed.). New York, N.Y.: Wiley.

James, G. (2012). 5 traits of highly successful salesmen. Retrieved July 27, 2013, from http://www.inc.com/geoffrey-james/5-traits -of-highly-successful-salesmen.html

Jung, C. G. (1990). Analytical psychology: Its theory and practice (The Tavistock lectures). New York, N.Y.: Vintage.

Khanna, V. (2011). 28 essential qualities of a successful salesman. Retrieved July 31, 2013, from http://www.preservearticles.com/ 201103064422/qualities-of-a-successful-salesman.html

Lanning, K. (1994). Dimensionality of observer ratings on the California Adult Q-Set. Journal of Personality and Social Psychology, 67, 151-160.

Livesley, W. J. (2003). Diagnostic dilemmas in classifying personality disorder. In K. A. Phillips, M. B. First, \& H. A. Pincus (Eds.), Advancing DSM: Dilemmas in psychiatric diagnosis (pp. 153-189). Arlington, V.A.: American Psychiatric Association.

Martin, W. S. (2011). Seven personality traits of top salespeople. Retrieved July 30, 2013, from http://blogs.hbr.org/cs/2011/06/ the_seven_personality_traits_o.html

Mayer, D., \& Greenberg, H. M. (1964). What makes a good salesman. Harvard Business Review, 42, 119-125.

Mount, M. K., \& Barrick, M. R. (1995). The big five personality dimensions: Implications for research and practice in human resources management. Research in Personnel and Human Resources Management, 13, 153-200.

Mount, M. K., Barrick, M. R., \& Stewart, G. L. (1998). Five-factor model of personality and job performance in jobs involving interpersonal interactions. Human Performance, 11, 145-165.

Pindelski M. (2011). Building sales department: Conclusions for implementing strategy. In S. Hittmar (Ed.), Theory of management, the selected problems for the development support of management knowledge base (Vol. 3, pp. 151-159). University of Zilina.

Rapaille, G. C., \& Coutu, D. (2006). Leveraging the psychology of the salesperson. A conversation with psychologist and anthropologist G. Clotaire Rapaille. Harvard Business Review, 84(7), 44-47.

Saucier, G. (1997). Effects of variable selection on the factor structure of person descriptors. Journal of Personality and Social Psychology, 73, 1296-1312.

Sheldon, W. H. (1942). The varieties of temperament: A psychology of constitutional differences. New York, N.Y.: Harper \& Brothers.

Tupes, E. C., \& Christal, R. E. (1961). Recurrent personality factors based on traits ratings. Journal of Personality, 60, $225-251$.

Vinchur, A. J., Shippmann, J. S., Switzer, F. S., \& Roth, P. L. (1998). A meta-analytic review of predictors of job performance for salespeople. Journal of Applied Psychology, 83, 586-597.

Warr, P., Bartram, D., \& Martin, T. (2005). Personality and sales performance: Situational variation and interactions between traits. International Journal of Selection and Assessment, 13(1), 87-91.

Young Entreprenur Council (YEC). (2013). 13 traits of an outstanding salesperson. Retrieved July 30, 2013, from http://www.inc.com/young-entrepreneur-council/13-qualities-to-look-for-in-your-next-sales-hire.html

Zukowska, J., \& Pindelski, M. (2010). Coaching as a tool supporting teamwork in organizations, including virtual ones. In Z. E. Zieliński (Ed.), Rola informatyki w naukach ekonomicznych i społecznych: Innowacje i implikacje interdyscyplinarne (The role of informatics in economics and social sciences: Innovations and interdisciplinary implications) (Vol. I, pp. 269-275). Kielce: Wydawnictwo Wyższej Szkoły Handlowej. 